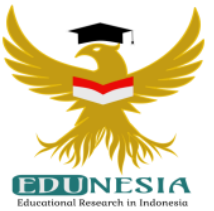

\title{
Persepsi Mahasiswa Pendidikan Bahasa Inggris UIN Sunan Ampel Surabaya Terhadap Pembelajaran Daring Via Zoom Pada Masa Pandemi Covid-19
}

\author{
Siti Uswatun Khasanah'; Ainun Syarifah² \\ 1,2 Pendidikan Bahasa, UIN Sunan Ampel Surabaya, Indonesia \\ ${ }^{1}$ Corresponding Email: sitiuswatun47@gmail.com, Phone Number: 0857 xxxx xxxxx
}

Article History:

Received: Agust 17, 2020

Revised: Sept 13, 2020

Accepted: Sept 17, 2020

Published: Jan 01,2021

Keywords:

Online Learning, Zoom,

Covid-19 Pandemic

Kata Kunci:

Pembelajaran Daring, Zoom, Pandemi Covid-19

How to cite:

Khasanah, S.U., \& Syarifah, A. (2021). Persepsi Mahasiswa Pendidikan Bahasa Inggris UIN Sunan Ampel Surabaya Terhadap Pembelajaran Daring Via Zoom Pada Masa Pandemi Covid-19. Edunesia : Jurnal Ilmiah Pendidikan, 2 (1): 23-33

This is an open access article under the $C C-B Y-N C-N D$ license

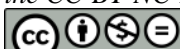

\begin{abstract}
This study aims to determine the perceptions of English Language Education students of UIN Sunan Ampel Surabaya on online learning via Zoom during the Covid-19 pandemic. The qualitative descriptive method was carried out by distributing questionnaires using Google Form to 45 English Education students at UIN Sunan Ampel Surabaya after completing the learning process for 3 months. The results of this study show that (1) the use of Zoom application provides new experiences in online learning activities, (2) students can easily operate some of the Zoom application features, (3) the learning process expects students to use the Zoom application, (4) the Zoom application is one of the e-learning tools that can support online learning activities continuously, (5) the use of Zoom application because the classmates agree to use the Zoom application, and (6) students can use the Zoom application easily in carrying out of online learning activities.
\end{abstract}

Abstrak: Penelitian ini bertujuan untuk mengetahui persepsi mahasiswa Pendidikan Bahasa Inggris UIN Sunan Ampel Surabaya terhadap pembelajaran daring via Zoom pada masa pandemi Covid-19. Metode deskritif kualitatif dilakukan dengan menyebar angket kuesioner menggunakan Google Form kepada 45 mahasiswa Pendidikan Bahasa Inggris UIN Sunan Ampel Surabaya setelah menyelesaikan proses pembelajaran selama 3 bulan. Hasil dari penelitian ini menyatakan bahwa (1) penggunaan aplikasi Zoom memberikan pengalaman baru dalam aktivitas pembelajaran daring, (2) mahasiswa dapat dengan mudah mengoperasikan beberapa fitur aplikasi Zoom, (3) proses pembelajaran mengharapkan mahasiwa untuk menggunakan aplikasi Zoom, (4) aplikasi Zoom merupakan salah satu e-learning yang dapat mendukung aktivitas pembelajaran secara daring, (5) penggunaan aplikasi Zoom karena para teman sekelas menyetujui untuk menggunakan aplikasi Zoom, (6) serta para mahasiswa dapat menggunakan aplikasi Zoom dengan mudah dalam melakukan aktivitas pembelajaran daring. 


\section{A. Pendahuluan}

Dunia dikagetkan dengan munculnya wabah pneumonia baru yang bermula dari Wuhan, Provinsi Hubei, China pada awal 2020. Kemudian merebak dengan cepat ke ratusan negara di dunia (Susilo dkk, 2020). Kasus pneumonia tersebut pada awalnya disebut sebagai 2019 novel coronavirus (2019-nCoV), kemudian World Health Organization (WHO) mengumumkan nama baru menjadi Coronavirus Disease (Covid-19) (WHO, 2020). Pada tanggal 11 Maret, 2020 (WHO) bahkan telah mendeklarasikan kasus ini sebagai pandemi global (Cucinotta \& Vanelli, 2020). Sebagai salah satu negara yang terdampak Covid-19 menyebabkan perekonomian Indonesia menjadi merosot, menjatuhkan nilai tukar rupiah dan juga mengakibatkan harga barang terutama alat-alat kesehatan menjadi mahal. Tidak hanya masalah tersebut, tetapi juga berdampak kepada sistem pendidikan di Indonesia. Pemerintah terpaksa harus meliburkan sementara kegiatan pembelajaran tatap muka di dalam kelas.

Salah satu tindakan pemerintah Indonesia untuk menanggulangi kasus di bidang pendidikan dengan mengeluarkan Surat Edaran Menteri Pendidikan dan Kebudayaan Nomor 4 Tahun 2020 yang mengatur tentang Pelaksanaan Kebijakan Pendidikan dalam Masa Darurat Penyebaran Covid-19 yang berisi himbauan agar kegiatan proses belajar mengajar dilaksanakan di rumah (Fajrian, 2020). Di dalam surat tersebut menyatakan bahwa proses belajar dilaksanakan di rumah melalui pembelajaran online atau pembelajaran daring (dalam jaringan) (Kemendikbud RI, 2020). Hal ini dilakukan sebagai antisipasi untuk mencegah dan memutus rantai penyebaran virus Covid-19, menjaga keselamatan serta keamanan peserta didik dan tenaga pendidik di lingkungan sekolah maupun perguruan tinggi.

Krisis kesehatan yang diakibatkan oleh wabah COVID-19 telah mempelopori pembelajaran daring secara serempak hampir di seluruh dunia (Goldschmidt, 2020). Guru dan pendidik sebagai elemen penting dalam proses belajar mengajar di haruskan untuk melakukan perubahan besar-besaran yang belum terjadi sebelumnya dari pendidikan tatap muka konvensional menuju pendidikan daring atau pendidikan jarak jauh (Bao, 2020; Basilaia \& Kvavadze, 2020). Adanya revolusi industri 4.0 saat ini, menyebabkan perkembangan teknologi kian tidak terbatas. Hal ini dapat mendukung pembelajaran daring berjalan secara efektif sehingga proses pembelajaran dapat terlaksana meskipun para pendidik dan peserta didik berada di tempat yang berbeda (Verawardina dkk., 2020). Selain itu, pembelajaran daring dilakukan sebagai alternatif agar proses belajar tetap terlaksana dan peserta tetap dapat belajar seperti biasanya meskipun pembelajaran tatap muka tidak dapat dilaksanakan secara langung (Herliandry dkk, 2020). Sehingga para peserta didik tidak dapat mengikuti materi pembelajaran serta waktu yang lebih fleksibel. Ini diharapkan mampu untuk menyelesaikan permasalahan keterlambatan peserta didik dalam memperoleh ilmu pengetahuan.

Para perguruan tinggi yang sebelumnya telah melakukan pembelajaran tatap muka secara langsung, kini juga harus menyesuaikan dengan model pembelajaran jarak jauh atau pembelajaran daring. Pembelajaran daring dapat dilakukan dengan memanfaatkan teknologi dan media internet. Keuntungan dari penggunaan pembelajaran secara daring adalah proses belajar mengajar bersifat mandiri dan memiliki interaktivitas yang tinggi, mampu meningkatkan daya ingat, memberikan lebih banyak pengalaman belajar dengan video, teks, audio, dan animasi yang semuanya dapat digunakan untuk menyampaikan informasi, dan juga memberikan kemudahan dalam penyampaian, 
memperbarui isi, mengunduh (Arnesti \& Hamid, 2015). Selain itu, para siswa juga dapat berkirim pesan elektronik kepada sesama temannya, menggunakan ruang chat, saling berbalas komentar pada forum diskusi, hingga berbagi link video conference yang dapat digunakan untuk berkomunikasi secara tatap muka langsung (Arnesti \& Hamid, 2015). Pembelajaran daring muncul sebagai salah satu alternatif belajar bagi mahasiswa karena tidak mengharuskan mereka untuk hadir di kelas. Selain itu, pembelajaran daring juga dapat mendorong mahasiswa lebih interaktif serta dapat menciptakan kemandirian dalam belajar. Sedangkan bagi dosen proses pembelajaran online dapat berdampak kepada profesionalitas kerja karena berubahnya gaya mengajar tatap muka konvensional. Model pembelajaran daring juga memberikan kesempatan bagi dosen agar lebih efisien dalam memberikan penilaian dan mengevaluasi progres pembelajaran setiap mahasiswanya (Zhafira dkk, 2020).

Pandemi Covid-19 saat ini mendesak para dosen dan mahasiswa untuk melakukan pembelajaran daring, hal ini memaksa agar segera beradaptasi dan melakukan inovasi terkait pemanfaatan teknologi dalam pembelajaran (Ahmed dkk, 2020). Adaptasi yang dapat diterapkan dalam pembelajaran secara online atau daring (dalam jaringan) yakni dengan memanfaatkan platform berupa aplikasi, website, jejaring social maupun Learning Management System (Gunawan dkk, 2020). Salah satu aplikasi yang dapat digunakan untuk membantu kegiatan pembelajaran daring adalah Zoom Cloud Meeting. Zoom merupakan sebuah aplikasi yang dapat digunakan untuk melaksanakan kegiatan meeting atau diskusi secara bersama seperti bertatap muka langsung tanpa harus bertemu secara fisik. Selain itu, menggunakan Zoom dapat menunjang kebutuhan komunikasi di manapun dan kapanpun berada.

Aplikasi Zoom sebagai sebuah layanan konferensi video memiliki kemampuan yang praktis dalam menghadirkan suasana meeting secara daring. Dilansir dari idcloudhost.com, pengguna aktif Zoom kian bertambah pesat sekitar 2,22 juta per bulan sejak pandemi COVID-19 menyebar ke seluruh dunia per Maret 2020 lalu. Aplikasi berbayar ini dapat digunakan secara gratis dengan kapasitas pengguna maksimal 100 orang dan batasan waktu konferensi sekitar 40 menit. Aplikasi ini juga dilengkapi dengan fitur sharing screen yang mampu memfasilitasi kebutuhan pengajar dalam menyajikan bahan ajar layaknya pertemuan tatap muka di dalam kelas konvensional kepada para peserta didik (Naserly, 2020).

UIN Sunan Ampel Surabaya sebagai salah satu perguruan tinggi juga turut serta menerapkan tindak pencegahan infeksi virus corona dengan melakukan proses perkuliahan secara daring untuk melindungi seluruh civitas akademika melalui Surat Edaran Rektor UIN Sunan Ampel Nomor 406 Tahun 2020 terkait sterilisasi lingkungan kampus dalam upaya pencegahan penularan infeksi virus Covid-19. Sehingga mengharuskan kegiatan pembelajaran tatap muka secara lansung di kelas juga diganti dengan proses pembelajaran daring yang dilakukan di rumah masing- masing.

Beberapa penelitian tentang pembelajaran daring telah dilakukan oleh Firman \& Rahayu (2020) mengkaji tentang pembelajaran online di tengah pandemi Covid-19 hasilnya menunjukkan bahwa pembelajaran online memiliki fleksibilitas dalam pelaksanaannya serta mampu memacu motivasi siswa untuk lebih aktif dan mandiri dalam belajar. Sementara penelitian yang dilakukan oleh Maulana \& Hamidi (2020) tentang persepsi mahasiswa terhadap pembelajaran daring pada mata kuliah praktik di pendidikan vokasi dengan hasil penelitian menunjukkan bahwa persepsi mahasiswa 
bersifat positif dengan rincian aspek belajar mengajar sebesar $66,4 \%$, aspek kapabilitas (kemampuan dosen) sebesar 74,6\%, dan aspek sarana dan prasarana sebesar 72,7\%.

Berdasarkan penelitian yang telah dilakukan sebelumnya, temuan mereka umumnya menunjukkan tentang penerapan pembelajaran daring secara umum. Namun, tampaknya mereka belum membahas penelitian yang lebih spesifik dan mendalam tentang satu media tertentu seperti aplikasi Zoom yang digunakan untuk pembelajaran daring serta secara spesifik yang membahas pembelajaran daring pada prodi Pendidikan Bahasa Inggris. Oleh karena itu, penelitian ini dilakukan untuk mengisi kekosongan tersebut dengan mengetahui persepsi mahasiswa Pendidikan Bahasa Inggris UIN Sunan Ampel Surabya terhadap pembelajaran daring via Zoom pada masa pandemi Covid-19. Hasil dari penelitian ini diharapkan dapat membantu proses pembelajaran daring untuk mengetahui tanggapan mahasiswa dalam penggunaan Zoom selama masa Covid-19.

\section{B. Metode}

Penelitian ini menggunakan metode deskritif kualitatif. Berdasarkan Moleong (2011) penelitian kualitatif adalah penelitian yang bermaksud untuk memahami fenomena tentang apa yang dialami oleh subjek penelitian secara holistik dan dengan cara deskripsi dalam bentuk kata-kata dan bahasa, pada suatu konteks khusus yang alamiah dan dengan memanfaatkan berbagai metode alamiah. Metode ini untuk mengkaji persepsi mahasiswa Pendidikan Bahasa Inggris UINSA terhadap pembelajaran daring via Zoom pada masa pandemi Covid-19.

Subjek penelitian ini adalah 45 mahasiswa prodi Pendidikan Bahasa Inggris UIN Sunan Ampel Surabaya dari semester 2, 4 dan 6 yang telah terlibat dalam pembelajaran daring via Zoom selama masa pandemi Covid-19 sejak bulan maret hingga Juni 2020. Pengumpulan sampel dilakukan dengan menggunakan teknik non probability sampling dengan pendekatan convenience sampling. Menurut Sugiyono (2016) non-probability sampling adalah teknik pengambilan sampel yang tidak memberi peluang ataukesempatan sama bagi setiap unsur atau anggota populasi untuk dipilih menjadi sampel. Sedangkan convenience sampling yaitu pengambilan sampel yang dilakukan secara kebetulan, yaitu siapa saja yang secara kebetulan bertemu dengan peneliti dapat digunakan sebagai sampel (Sugiyono, 2016).

Pengumpulan data dilakukan dengan menyebarkan angket kuesioner secara daring menggunakan Google Form dengan jumlah pertanyaan sebanayak 25 poin yang dikirimkan kepada mahasiswa melalui pesan WhatsApp. Para mahasiswa diminta kesediannya untuk mengisi kuesioner yang telah dibagikan setelah proses pembelajaran dilaksanakan secara daring. Kuesioner menggunakan skala Likert lima poin yakni Sangat Setuju (SS), Setuju (S), Netral (N), Tidak Setuju (TS), dan Sangat Tidak Setuju (STS). Data yang didapat dari angket tersebut disajikan dalam bentuk tabel untuk mengetahui kecenderungan persepsi mahasiswa terhadap perkuliahan online menggunakan aplikasi Zoom pada masa pandemi Covid-19.

Analisis data dari hasil penelitian ini menggunakan model interaktif kualitatif yang terdiri dari tiga tahapan, yakni reduksi data, display data, serta penarikan dan verifikasi kesimpulan. Pertama, pada tahap reduksi data adalah tahap ketika mengumpulkan seluruh informasi yang dibutuhkan dari hasil kuesioner kemudian di kelompokkan datanya. Kedua, tahap display data yakni tahap pemaparan data yang diperlukan dalam penelitian. Ketiga, tahap penarikan dan verifikasi kesimpulan adalah 
tahap interpretasi data penelitian kemudian ditarik kesimpulan berdasarkan fenomena yang telah diperoleh (Saldana dkk, 2014).

\section{Hasil dan Pembahasan}

Setelah melalui proses analisis, hasil penelitian dipaparkan dalam tabel dengan melihat presentase tertinggi untuk mengetahui persepsi mahasiswa mengenai penggunaan aplikasi Zoom selama mengikuti pembelajaran daring.

Tabel 1.

Ekspektansi Kinerja pada penggunaan aplikasi Zoom

\begin{tabular}{|c|c|c|c|c|c|}
\hline Ekspektansi Kinerja & SS & $S$ & $\mathbf{N}$ & TS & STS \\
\hline $\begin{array}{l}\text { Saya merasa bahwa aplikasi zoom dapat } \\
\text { membantu aktivitas pembelajaran daring } \\
\text { menjadi lebih mudah. }\end{array}$ & $15,6 \%$ & $51,1 \%$ & $20 \%$ & $13,3 \%$ & - \\
\hline $\begin{array}{l}\text { Saya merasa bahwa aplikasi zoom relevan } \\
\text { digunakan untuk aktivitas pembelajaran } \\
\text { daring. }\end{array}$ & $15,6 \%$ & $37,8 \%$ & $33,3 \%$ & $13,3 \%$ & - \\
\hline $\begin{array}{l}\text { Saya merasa bahwa aplikasi zoom } \\
\text { memberikan manfaat dalam aktivitas } \\
\text { pembelajaran daring selama pandemic covid- } \\
19\end{array}$ & $17,8 \%$ & $57,8 \%$ & $20 \%$ & $4,4 \%$ & - \\
\hline $\begin{array}{l}\text { Saya merasa bahwa aplikasi zoom } \\
\text { memberikan pengalaman baru dalam aktivitas } \\
\text { pembelajaran daring selama pandemi covid- } \\
19\end{array}$ & $31,1 \%$ & $62,2 \%$ & $6,7 \%$ & - & - \\
\hline $\begin{array}{l}\text { Dengan menggunakan aplikasi zoom dapat } \\
\text { lebih efisien untuk menjalin komunikasi } \\
\text { antara dosen dan mahasiswa. }\end{array}$ & $13,3 \%$ & $55,6 \%$ & $20 \%$ & $8,9 \%$ & $2,2 \%$ \\
\hline $\begin{array}{l}\text { Dengan menggunakan aplikasi zoom dapat } \\
\text { meningkatkan peluang keberhasilan } \\
\text { pembelajaran yang telah direncanakan. }\end{array}$ & $4,4 \%$ & $28,9 \%$ & $53,3 \%$ & $11,1 \%$ & $2,2 \%$ \\
\hline $\begin{array}{l}\text { Saya merasa bahwa kemampuan teknologi } \\
\text { informasi menjadi bekal penting untuk dapat } \\
\text { menggunakan aplikasi zoom }\end{array}$ & $11,1 \%$ & $57,8 \%$ & $28,9 \%$ & $2,2 \%$ & - \\
\hline $\begin{array}{l}\text { Saya merasa bahwa aplikasi zoom dapat } \\
\text { meningkatkan produktivitas selama masa } \\
\text { pandemi covid-19 }\end{array}$ & $8,9 \%$ & $44,4 \%$ & $40 \%$ & $4,4 \%$ & $2,2 \%$ \\
\hline $\begin{array}{l}\text { Saya merasa bahwa aplikasi zoom } \\
\text { memfasilitasi saya untuk lebih kreatif dalam } \\
\text { pembelajaran selama pandemi covid-19 }\end{array}$ & $6.7 \%$ & $40 \%$ & $40 \%$ & $11,1 \%$ & $2,2 \%$ \\
\hline
\end{tabular}

Tabel 1 menunjukkan hasil kuesioner dengan kriteria ekspektansi kinerja. Sebanyak 51,1\% mahasiswa menyetujui bahwa aplikasi Zoom dapat membantu mereka selama aktivitas pembelajaran daring menjadi lebih mudah. Kemudian sebanyak 37,8\% menyetujui bahwa aplikasi Zoom relevan digunakan untuk aktivitas pembelajaran 
daring. Sebanayak 57,8\% menyatakan setuju bahwa aplikasi Zoom memberikan manfaat dalam aktivitas pembelajaran daring selama pandemi Covid-19. Lalu, 62,2\% mahasiswa menyatakan setuju bahwa aplikasi Zoom memberikan pengalaman baru dalam aktivitas pembelajaran daring selama pandemi Covid-19. Sebanyak 55,6\% mahasiswa menyetujui bahwa dengan menggunakan aplikasi Zoom dapat lebih efisien untuk menjalin komunikasi antara dosen dan mahasiswa. Sedangkan 53,3\% mahasiswa memilih netral apabila dengan menggunakan aplikasi Zoom dapat meningkatkan peluang keberhasilan pembelajaran yang telah direncanakan. Kemudian sebanyak 57,8\% mahasiswa menyatakan setuju bahwa kemampuan teknologi informasi menjadi bekal penting untuk dapat menggunakan aplikasi Zoom. Lalu, sebanyak 44,4\% mahasiswa menyatakan sejutu bahwa aplikasi Zoom dapat meningkatkan produktivitas selama masa pandemi Covid19. Sedangkan $40 \%$ mahasiswa memilih netral dan menyutujui bahwa aplikasi Zoom memfasilitasi untuk lebih kreatif dalam pembelajaran selama pandemi Covid-19. Dari hasil tersebut menunjukkan bahwa ekspektansi kinerja penggunaan aplikasi Zoom menunjukkan hal yang positif karena presentase tertinggi menyatakan mahasiswa Pendidikan Bahasa Inggris banyak menyetujui bahwa penggunaan aplikasi Zoom sebagai pembelajaran daring selama masa pandemi Covid-19.

Tabel 2

Ekspektansi Usaha pada penggunaan aplikasi Zoom

\begin{tabular}{lcccccc}
\hline \multicolumn{2}{c}{ Ekspektansi Usaha } & SS & S & N & TS & STS \\
\hline $\begin{array}{l}\text { Saya dapat dengan mudah mengoperasikan } \\
\text { aplikasi zoom }\end{array}$ & $28,9 \%$ & $60 \%$ & $8,9 \%$ & $2,2 \%$ & - \\
\hline $\begin{array}{l}\text { Saya dapat dengan mudah mengoperasikan } \\
\text { beberapa fitur aplikasi zoom }\end{array}$ & $17,8 \%$ & $55,6 \%$ & $22,2 \%$ & $4,4 \%$ & - \\
\hline $\begin{array}{l}\text { Dengan menggunakan aplikasi zoom dapat } \\
\text { membuat kegiatan pembelajaran semakin rumit }\end{array}$ & $8,9 \%$ & $8,9 \%$ & $57,8 \%$ & $24,4 \%$ & - \\
\hline $\begin{array}{l}\text { Dengan menggunakan aplikasi zoom } \\
\text { memungkinkan saya untuk menyelesaikan } \\
\text { beberapa mata kuliah dengan lebih efektif }\end{array}$ & $6,7 \%$ & $22,2 \%$ & $55,6 \%$ & $15,6 \%$ & - \\
\hline
\end{tabular}

Tabel 2 menunjukan hasil kuesioner dengan kriteria ekspektansi usaha pada penggunaan aplikasi Zoom. Dapat diketahui bahwa 60\% mahasiswa menyetujui dapat dengan mudah mengoperasikan aplikasi Zoom. Lalu sebanyak 55,6\% mahasiswa menyatakan setuju bahwa mereka dapat dengan mudah mengoperasikan beberapa fitur aplikasi Zoom. Sedangkan 57,8\% mahasiswa milih netral untuk menyatakan bahwa dengan menggunakan aplikasi Zoom dapat membuat kegiatan pembelajaran semakin rumit. Sebanyak 55,6\% mahasiswa menyatakan netral bahwa dengan menggunakan aplikasi Zoom memungkinkan mereka untuk menyelesaikan beberapa mata kuliah dengan lebih efektif. Hasil tersebut menunjukkan bahwa pada kriteria ekspektansi usaha penggunaan aplikasi Zoom menunjukkan respon positif karena mahasiswa Pendidikan Bahasa Inggris selain menyetujui tetapi mereka juga memilih netral dengan presentase yang tinggi untuk penggunaan aplikasi Zoom sebagai pembelajaran daring selama masa pandemi Covid-19. 
Tabel 3.

Faktor Sosial pada penggunaan aplikasi Zoom

\begin{tabular}{lccccc}
\hline \multicolumn{1}{c}{ Faktor Sosial } & SS & S & N & TS & STS \\
\hline $\begin{array}{l}\text { Saya menggunakan aplikasi zoom karena } \\
\text { pengaruh dari orang lain }\end{array}$ & $13,3 \%$ & $35,6 \%$ & $24,4 \%$ & $22,2 \%$ & $4,4 \%$ \\
\hline $\begin{array}{l}\text { Saya nyaman menggunakan aplikasi zoom. } \\
\text { Karena ada beberapa orang yang membantu } \\
\text { saya dalam menggunakan aplikasi zoom. }\end{array}$ & $4,4 \%$ & $15,6 \%$ & $51,1 \%$ & $24,4 \%$ & $4,4 \%$ \\
\hline $\begin{array}{l}\text { Saya menggunakan aplikasi zoom karena } \\
\text { proses pembelajaran mengharapkan saya } \\
\text { untuk menggunakan aplikasi zoom. }\end{array}$ & & & & & \\
\hline
\end{tabular}

Tabel 3 merupkan hasil kuesioner dengan kriteria faktor sosial pada penggunaan aplikasi Zoom. Presentase tertinggi menunjukkan bahwa sebanyak 35,6\% mahasiswa sejutu jika mereka menggunakan aplikasi Zoom karena pengaruh dari orang lain. Sedangkan sebanyak 51,1\% mahasiswa memilih netral ketika menggunakan aplikasi Zoom, karena ada beberapa orang yang membantu mereka dalam menggunakan aplikasi Zoom. Kemudian 44,4\% mahasiswa sangat setuju bahwa karena proses pembelajaran mengharapkan mereka untuk menggunakan aplikasi Zoom. Hasil tersebut menyatakan bahwa mahasiswa menggunakan Zoom karena faktor sosial yakni pengaruh pada mata kuliah tertentu yang menghapakan mahasiswa untuk menggunakan Zoom.

Tabel 4.

Kondisi yang Memfasilitasi pada penggunaan aplikasi Zoom

\begin{tabular}{|c|c|c|c|c|c|}
\hline Kondisi yang Memfasilitasi & SS & $S$ & $\mathbf{N}$ & TS & STS \\
\hline $\begin{array}{l}\text { Saya nyaman menggunakan aplikasi zoom } \\
\text { karena dapat digunakan dengan mudah }\end{array}$ & $13,3 \%$ & $35,6 \%$ & $42,2 \%$ & $8,9 \%$ & - \\
\hline $\begin{array}{l}\text { Saya nyaman menggunakan aplikasi zoom } \\
\text { karena saya memiliki kemampuan untuk } \\
\text { menggunakannya. }\end{array}$ & $13,3 \%$ & $40 \%$ & $42,2 \%$ & $4,4 \%$ & - \\
\hline $\begin{array}{l}\text { Saya menggunakan aplikasi zoom karena } \\
\text { fungsi yang disediakan aplikasi zoom sesuai } \\
\text { dengan kebutuhan aktivitas pembelajaran } \\
\text { daring. }\end{array}$ & $11,1 \%$ & $42,2 \%$ & $44,4 \%$ & $2,2 \%$ & - \\
\hline $\begin{array}{l}\text { Saya merasa bahwa aplikasi zoom } \\
\text { merupakan salah satu e-learning yang dapat } \\
\text { mendukung aktivitas pembelajaran secara } \\
\text { daring. }\end{array}$ & $13,3 \%$ & $64,4 \%$ & $22,2 \%$ & - & - \\
\hline $\begin{array}{l}\text { Saya merasa bahwa penggunaan aplikasi } \\
\text { zoom yang disarankan oleh dosen saya } \\
\text { penting untuk menunjang kemampuan IT } \\
\text { saya. }\end{array}$ & $15,6 \%$ & $48,9 \%$ & $24,4 \%$ & $8,9 \%$ & - \\
\hline
\end{tabular}

Tabel 4 menunjuukan hasil kuesioner dengan kriteria kondisi yang memfasilitasi. Prosentase tertinggi menunjukkan bahwa sebanyak 42,2\% mahasiswa memilih netral dan 
35,6\% menyetujui menggunakan aplikasi Zoom karena dapat digunakan dengan mudah. Kemudian, sebanyak 42,2\% mahasiswa memilih netral dan $40 \%$ menyetujui menggunakan aplikasi Zoom mereka memiliki kemampuan untuk menggunakannya. Hal yang sama menunjuuka bahwa 44,4\% memilih netral dan 42,2\% menyetujui menggunakan aplikasi Zoom karena fungsi yang disediakan aplikasi Zoom sesuai dengan kebutuhan aktivitas pembelajaran daring.

Selain itu, sebanyak 64,4\% mahasiswa menyetujui bahwa aplikasi Zoom merupakan salah satu e-learning yang dapat mendukung aktivitas pembelajaran secara daring. Kemudian 48,9\% menyatakan setuju bahwa penggunaan aplikasi Zoom yang disarankan oleh dosen penting untuk menunjang kemampuan IT mereka. Hasil tersebut menunjukkan bahwa pada kriteria kondisi yang memfasilitasi penggunaan aplikasi Zoom menunjukkan respon yang positif karena para mahasiswa pendidikan Bahasa Inggris menyatakan bahwa aplikasi Zoom merupakan salah satu media yang dapat digunakan untuk mendukung aktivitas dalam pembelajaran daring selama pandemi Covid-19.

Tabel 5.

Minat Pemanfaatan pada penggunaan aplikasi Zoom

\begin{tabular}{lccccc}
\hline \multicolumn{1}{c}{ Minat Pemanfaatan } & SS & S & N & TS & STS \\
\hline $\begin{array}{l}\text { Saya ingin terus menerus menggunakan } \\
\text { aplikasi zoom untuk aktivitas pembelajaran } \\
\text { secara daring. }\end{array}$ & $6,7 \%$ & $4,4 \%$ & $35,6 \%$ & $35,6 \%$ & $17,8 \%$ \\
\hline $\begin{array}{l}\text { Saya menggunakan aplikasi zoom karena } \\
\text { para teman sekelas menyetujui untuk } \\
\text { menggunakan aplikasi zoom. }\end{array}$ & $13,3 \%$ & $37,8 \%$ & $45,7 \%$ & $2,2 \%$ & - \\
\hline
\end{tabular}

Tabel 5 menyatakan hasil kuesioner dengan kriteria minat pemanfaatan pada penggunaan aplikasi Zoom. Presentase tertinggi menyatakan bahwa sebanyak 35,6\% mahasiswa memilih netral dan tidak setuju jika terus-menerus menggunakan aplikasi Zoom untuk aktivitas pembelajaran secara daring. Selain itu sebanyak $45 \%$ mahasiswa juga memilih netral dengan pernyataan bahwa menggunakan aplikasi Zoom karena para teman sekelas menyetujui untuk menggunakan aplikasi Zoom. Hasil tersebut menunjukkan bahwa pada kriteria minat pemanfaatan dalam penggunaan aplikasi Zoom menunjukkan respon kurang positif karena mahasiswa Pendidikan Bahasa Inggris lebih memilih untuk netral dengan presentase yang cukup tinggi untuk penggunaan aplikasi Zoom sebagai pembelajaran daring selama masa pandemi Covid-19. Hal ini menandakan mereka kurang berminat untuk menggunakan Zoom.

Tabel 6.

Perilaku Penggunaan pada penggunaan aplikasi Zoom

\begin{tabular}{lcccccc}
\hline \multicolumn{1}{c}{ Perilaku Penggunaan } & SS & S & N & TS & STS \\
\hline $\begin{array}{l}\text { Saya dapat menggunakan aplikasi zoom } \\
\text { dengan mudah dalam melakukan aktivitas } \\
\text { pembelajaran daring. }\end{array}$ & $15,6 \%$ & $46,7 \%$ & $35,6 \%$ & $2,2 \%$ & - \\
\hline Saya merasa bahwa aplikasi zoom & $4,4 \%$ & $11,1 \%$ & $40 \%$ & $37,8 \%$ & $6,7 \%$ \\
\hline
\end{tabular}




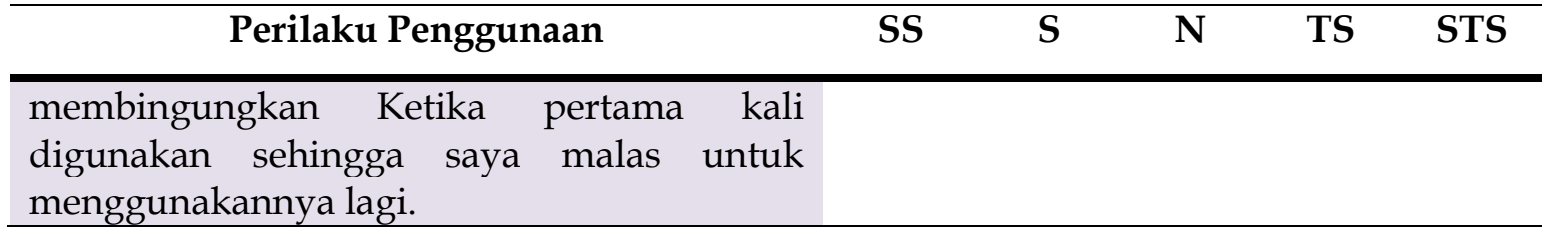

Tabel 6 menyatakan hasil kuesioner tentang kriteria perilaku penggunaan pada penggunaan aplikasi Zoom. Presentase tertinggi menyatakan bahwa 46,7\% mahasiswa setuju bahwa mereka dapat menggunakan aplikasi Zoom dengan mudah dalam melakukan aktivitas pembelajaran daring. Kemudian 40\% mahasiswa memilih netral dan $37,8 \%$ menyakan tidak setuju jika aplikasi Zoom membingungkan ketika pertama kali digunakan. Hasil tersebut menunjukkan bahwa pada kriteria perilaku penggunaan dalam penggunaan aplikasi Zoom menunjukkan respon yang positif karena mahasiswa Pendidikan Bahasa Inggris menyatakan bahwa aplikasi Zoom mudah digunakan dan cara penggunaannya tidak membingungkan.

Dari hasil pengolahan data penelitian yang telah dilakukan, menunjukkan respon yang positif dari persepsi mahasiswa Pendidikan Bahasa Inggris, UIN Sunan Ampel Surabaya terhadap penggunaan Zoom selama masa pandemi Covid-19. Hal ini diketahui dari setiap item kuesioner, rata-rata presentase respon mahasiswa menunjukkan di atas $30 \%$. Hal ini sejalan dengan penyataan Ismawati \& Prasetyo (2020) bahwa pembelajaran dengan video conference menggunakan aplikasi zoom ternyata efektif, interkatif, dapat mendukung pembelajaran jarak jauh, memudahkan anak didik untuk menyerap materi pembelajaran yang disampaikan pendidik karena lebih real time.

\section{Kesimpulan}

Hasil penelitian tersebut menunjukkan bahwa penggunaan aplikasi Zoom memberikan pengalaman baru dalam aktivitas pembelajaran daring (62,2\%). Mahasiswa menyetujui dapat dengan mudah mengoperasikan beberapa fitur aplikasi Zoom (55,6\%) . Mahasiswa sangat setuju bahwa proses pembelajaran mengharapkannya untuk menggunakan aplikasi Zoom (44,4\%). Aplikasi Zoom merupakan salah satu e-learning yang dapat mendukung aktivitas pembelajaran secara daring $(64,4 \%)$. Penggunaan aplikasi Zoom karena para teman sekelas menyetujui untuk menggunakan aplikasi Zoom $(37,8 \%)$ serta para mahasiswa dapat menggunakan aplikasi Zoom dengan mudah dalam melakukan aktivitas pembelajaran daring (51,1\%). Selama pandemi Covid-19, guru maupun dosen dapat menggunakan aplikasi Zoom sebagai media pembelajaran. Karena selain menjadi media pengganti pembelajaran tatap muka secara langsung, mahasiswa juga menunjukkan respon yang positif terhadap penggunaan aplikasi Zoom. Dari mengetahui persepsi mahasiswa, dapat diketahui bahwa media zoom dapat digunakan sebagai media pembelajaran. Sehingga pembelajaran daring dapat berjalan dengan lancar. Untuk penelitian lebih lanjut, dapat dilakukan tentang persepsi penggunaan media pembelajaran Zoom bagi para guru atau pendidik. Sehingga akan diketahui persepsi dari kedua pihak yakni pendidik dan juga peseta didik. 


\section{Daftar Pustaka}

Ahmed, S., Shehata, M., \& Hassanien, M. (2020). Emerging faculty needs for enhancing student engagement on a virtual platform. MedEdPublish, 9(1). doi: 10.15694/mep.2020.000075.1

Arnesti, N., \& Hamid, A. (2015). Penggunaan media pembelajaran online - offline dan komunikasi interpersonal terhadap hasil belajar bahasa inggris. Jurnal Teknologi Informasi \& Komunikasi Dalam Pendidikan, 2(1). doi: 10.24114/jtikp.v2i1.3284

Bao, W. (2020). Covid-19 and online teaching in higher education: A case study of Peking University. Human Behavior and Emerging Technologies, 2(2), 113-115. doi: 10.1002/hbe2.191

Basilaia, G., \& Kvavadze, D. (2020). Transition to online education in schools during a sars-cov-2 coronavirus (Covid-19) pandemic in Georgia. Pedagogical Research, 5(4). doi: $10.29333 / \mathrm{pr} / 7937$

Cucinotta, D., \& Vanelli, M. (2020). WHO declares covid-19 a pandemic. Acta Bio Medica Atenei Parmensis, 91(1), 157-160. doi: 10.23750/abm.v91i1.9397

Firman, F., \& Rahayu, S. (2020). Pembelajaran online di tengah pandemi covid-19. Indonesian Journal of Educational Science (IJES), 2(2), 81-89. doi: 10.31605/ijes.v2i2.659

Goldschmidt, K. (2020). The covid-19 pandemic: Technology use to support the wellbeing of children. Journal of Pediatric Nursing, 53, 88-90. doi: 10.1016/j.pedn.2020.04.013

Gunawan, G., Suranti, N. M. Y., \& Fathoroni, F. (2020). Variations of models and learning platforms for prospective teachers during the covid-19 pandemic period. Indonesian Journal of Teacher Education, 1(2), 61-70.

Herliandry, L. D., Nurhasanah, N., Suban, M. E., \& Kuswanto, H. (2020). Pembelajaran pada masa pandemi covid-19. JTP - Jurnal Teknologi Pendidikan, 22(1), 65-70. doi: 10.21009/jtp.v22i1.15286

Ismawati, D., \& Prasetyo, I. (2020). Efektivitas pembelajaran menggunakan video zoom cloud meeting pada anak usia dini era pandemi covid-19. Jurnal Obsesi: Jurnal Pendidikan Anak Usia Dini, 5(1), 665. doi: 10.31004/obsesi.v5i1.671

Maulana, H. A., \& Hamidi, M. (2020). Persepsi mahasiswa terhadap pembelajaran daring pada mata kuliah praktik di pendidikan vokasi. Equilibrium: Jurnal Pendidikan, 8(2), 224-231.

Moleong, L. J. (2011). Metodologi penelitian kualitatif edisi revisi. Bandung: PT. Remaja Rosdakarya. 
Naserly, M. (2020). Implementasi zoom, google classroom, dan whatsapp group dalam mendukung pembelajaran daring (online) pada mata kuliah bahasa inggris lanjut (Studi kasus pada 2 kelas semester 2, Jurusan Administrasi Bisnis, Fakultas Ekonomi dan Bisnis, Universitas Bina Sa. Aksara Public, 4(2). Retrieved from http://aksarapublic.com/index.php/home/article/view/417

Saldana, Miles, \& Huberman. (2014). Qualitative data analysis. Amerika: SAGE Publications.

Sugiyono. (2016). Metode penelitian kuantitatif, kualitatif dan rEd, Cetakan ke-24. Bandung: Alfabeta.

Susilo, A., Rumende, C. M., Pitoyo, C. W., Santoso, W. D., Yulianti, M., Herikurniawan, H., ... Yunihastuti, E. (2020). Coronavirus disease 2019: Tinjauan literatur terkini. Jurnal Penyakit Dalam Indonesia, 7(1), 45. doi: 10.7454/jpdi.v7i1.415

Verawardina, U., Asnur, L., Lubis, A. L., Hendriyan, Y., Ramadhani, D., Dewi, I. P., ... Sriwahyuni, T. (2020). Reviewing online learning facing the covid-19 outbreak. Talent Development E Excellence, 12(3), 385-392.

Zhafira, N. H., Ertika, Y., \& Chairiyaton, C. (2020). Persepsi mahasiswa terhadap perkuliahan daring sebagai sarana pembelajaran. Jurnal Bisnis Dan Kajian Strategi Manajemen, 4(1).

Fajrian, H. (n.d.). Antisipasi corona nadiem makarim dukung kebijakan meliburkan sekolah. Retrieved from https://katadata.co.id/

World Health Organization. (n.d.). Naming the coronavirus disease (COVID-19) and the virus that causes it.

Retrieved from https://www.who.int/emergencies/diseases/novel-coronavirus2019/technical-guidance/naming-the-coronavirus-disease-(covid-2019)-and-thevirus-that-causes-it.

Kemdikbud RI. (2020). Surat edaran entang pencegahan corona virus disease (covid-19) pada satuan pendidikan.

Mengenal aplikasi zoom : Cara install dan fitur-fitur zoom meeting. Retrieved from https://idcloudhost.com/ 